\title{
Intergenerational communication barriers and pitfalls of business families in transition-a qualitative action research approach
}

\author{
Anita Zehrer and Gabriela Leiß \\ Family Business Center, MCI The Entrepreneurial School, Innsbruck, Austria
}

Intergenerational communication barriers

Received 22 March 2020 Revised 8 May 2020 Accepted 7 June 2020

\begin{abstract}
Purpose - This paper aims to explore the pertinent issues, barriers and pitfalls of intergenerational communication in business families during their leadership succession period.

Design/methodology/approach - Building on relational leadership theory, the paper makes use of an action research approach using a qualitative single case study to investigate communication barriers and pitfalls in business transition.

Findings - Through action research, interventions were taken in the underlying case, which increased the consciousness, as well as the personal and social competencies of the business family. Thus, business families stuck in ambivalent entanglement understand their underlying motives and needs within the change process, get into closer contact with their emotional barriers and communication hindrances, which is a prerequisite for any change, and break the succession iceberg phenomenon.

Research limitations/implications - Future research should undertake multiple case studies to validate and/or modify the qualitative methods used in this action research to increase the validity and generalizability of the findings.

Practical implications - Given the large number of business families in transition, our study shows the beneficial effects action research might have on business families' communication behavior along a change process. The findings might help other business families to understand the value of action research for such underlying challenges and decrease communication barriers.

Originality/value - This is one of the few studies to have addressed intergenerational communication of business families using an action research approach.
\end{abstract}

Keywords Intergenerational communication, Business family, Family succession, Action research, Case study

Paper type Research paper

\section{Introduction}

Succession in family firms is the most delicate business transformation since numerous challenges arise at the interface of family and business that threaten the continuity of the firm (De Massis et al., 2008; Von Schlippe and Hermann, 2013). Intra-family leadership succession involves transferring the responsibility for a family firm from one generation to the next (Blumentritt et al., 2012; Ward, 2011). Family firms undergo various processes of change and transformation for their survival (Cabrera-Suárez et al., 2001; Murray, 2003; Bracci and Vagnoni, 2011; Durst and Wilhelm, 2012; Daspit et al., 2015), and many family firms fail

Published by Emerald Publishing Limited. This article is published under the Creative Commons Attribution (CCBY 4.0) licence. Anyone may reproduce, distribute, translate and create derivative works of this article (for both commercial and non-commercial purposes), subject to full attribution to the original publication and authors. The full terms of this licence may be seen at http://creativecommons. org/licences/by/4.0/legalcode.

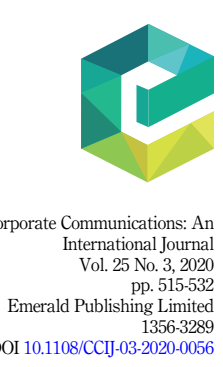


CCIJ

25,3

516

during the transition of leadership and/or ownership between generations (Morris et al., 1996; Bigliardi and Dormio, 2009).

Family firms, particularly family firm succession, is an emerging research area (Chrisman et al., 2008), and very little attention has been paid to communication within the business family during this transition process (Sorenson et al., 2013). Although researchers have acknowledged that intra-family succession in family businesses requires a lot of interaction and communication between the parties involved (Handler, 1989, 1994; Morris et al., 1996), we know very little about how communication dynamics can influence the succession process (Botero et al., 2013; Michael-Tsabari and Weiss, 2015). Communication between family members is scarcely mentioned in Le-Breton-Miller et al.'s (2004) review of the succession literature. Additionally, communication has rarely been included in conceptual models explaining succession (e.g. Cabrera-Suarez et al., 2001; Sharma et al., 2003; Le-Breton-Miller et al., 2004), neither has it been used as a secondary variable when exploring this process (Sharma et al., 2001, 2003; Dyck et al., 2002; Kaplan et al., 2009; De-Massis et al., 2008). While Sharma et al. (2003) explored the impact of communication between founder and successor on family harmony at the launching of the transition process, Blumentritt et al. (2012) delivered insights on deficient communication and communication traps during a transition process. To complement this, Michael-Tsabari and Weiss (2015) highlight a structural problem in the succession process and show how deficient communication leads to disagreements. They agree with Kaplan et al. (2009), who indicates that personal disappointments and strained relationships are responsible for passive communication among actors. However, according to Koerner and Fitzpatrick (2002), "family communication behaviour is largely the result of cognitive processes that are determined by family relationship schemas" (p. 87). Thus, in the context of family firms, researchers have used a grounded theory approach to develop a dynamic communication model identifying four major types of communication during a succession process (Leiß, 2014; Leiß and Zehrer, 2018).

Although communication during succession has been explored, there is not much research on barriers and pitfalls of communication during succession and their underlying dynamics in intergenerational communication. This is interesting given that, similar to marriage, family firm succession "represents a challenging and intriguing context in which to examine communication structures, dynamic functions and processes, and outcomes over time" (Fitzpatrick, 2004, p. 170). In an attempt to gain a deeper understanding of how business families experience the communication process during leadership transitions, this paper analyzes the barriers and pitfalls in communication during the succession process of a business family that owns and runs a hotel in the Austrian Alps. We use the dynamic communication model developed by Leiß (2014) and applied by Leiß and Zehrer (2018) as the basis of our work, and explore, using a case study, how interventions derived from the model helped them manage intergenerational communication barriers during the succession process. We show how the change process set up with the business family helped them in managing intergenerational communication barriers and pitfalls related to succession and supported them in developing an action plan for the power change between predecessors and successors.

\section{Theoretical background}

Succession in family firms

Succession is a multidimensional process rather than an event (e.g. Handler, 1994; CabreraSuárez, 2005; Drakopoulou et al., 2013; Duh, 2014); it takes time to develop and needs to be planned and managed (Barnes and Hershon, 1976; Davis, 1968; Morris et al., 1996; Sharma et al., 2001). During the transition period, several subjects are involved (Le-Breton-Miller et al., 2004), including the incumbent (Amrbose, 1983; Rubenson and Gupta, 1996), the successor 
(Birley, 1986; Barach et al., 1988; Handler, 1990; Birley, 2002), the family (Davis, 1968; Handler, 1994) and the firm's other internal and external stakeholders (Handler, 1989; Fox et al., 1996; Steier, 2001). Halter (2009) argues that succession cannot be reduced to the simple transfer of leadership and/or ownership at one point; it needs a more holistic approach over a certain period of time.

Succession in family firms can refer to leadership transition or ownership change, and often, a clear line is drawn between the two. "Ownership succession is defined as the complete and irreversible legal succession from one owner (group) to another. [...] Leadership succession is defined as the transfer of ultimate management responsibility from the person currently in charge (CEO, managing director, owner-manager) to another person [ . . ." (Davis and Klein, 2005, p. 59). Thus, ownership succession focuses on who will own and have legal rights over the business and when and how the transfer will happen; while leadership succession focuses on who will run the business, what changes will occur when are be accountable for results, and how results will be realized (Efendioglu and Mucat, 2009). Leadership succession can be very turbulent in family firms and is more challenging than ownership succession (Handler, 1994; Gbadegeshin, 2013). The focus of this paper is on leadership succession.

Leadership succession is a "(...) continuous process where leadership and power is transferred from one family member to the next (usually from one generation to the next), while maintaining positive family relationships, and enabling the business to continue to expand and prosper financially" (Griffeth et al., 2006 p. 492). Leadership succession is commonly described as a complex long-term process that also involves the dynamics before and after the actual leadership transfer (Blumentritt et al., 2012). This implies that a change in the executive suite can shake up the direction and politics of business. According to Blumentritt et al. (2012), "leadership succession involves transferring responsibility for the ongoing management of a family firm from members of a senior generation to members of junior generations, especially the replacing of a retiring CEO with a younger family member" (p. 54).

There have been multiple approaches to explain the succession process. Churchill and Hatten (1987) developed the life-cycle approach of succession, which outlines the succession process between father and son in a family business. The authors take the biological reality into account that parents and their children are separated by age and business experience but united by blood ties and a shared history. Moreover, they acknowledge the fact that an organization also undergoes certain development. In their work, Churchill and Hatten (1987) distinguish four stages of the succession process: (1) a stage of owner-management, where the owner is the only family member directly involved in the business, (2) a training and development stage, where the chosen successor gets to know the business, (3) a partnership stage, where both the predecessor and the successor work in the business, and finally, (4) a power transfer stage, where the successor takes over the responsibility of the business. Although this is a popular view of succession (Handler, 1994), business families tend to underestimate the duration and complexity of the leadership transition process, which may lead to negative outcomes for the business and the family (Motwani et al., 2006; Giarmarco, 2012).

Cabrera-Suárez (2005, p. 73) complement the life-cycle approach by suggesting the socialization process to which the family successor is exposed. Socialization represents a core concept in sociology and is defined as " (. . .) the process whereby the helpless infant gradually becomes a self-aware, knowledgeable person, skilled in the ways of the culture into which she or he is born" (Giddens as cited in Haag, 2012, p. 22). Through this process, children acquire role-specific knowledge that can amount to one of the strengths of family businesses. Thus, the socialization of family members is one of the components of succession. Furthermore, Haag (2012) reasons that "Based on our socialization we make sense of our lives even if we 
CCIJ

25,3

518

cannot spell out exactly what that involves; it constitutes our background coping skills on which we unconsciously draw to deal with novel situations" (p. 24). This is in line with the psychodynamic approach described by Kets de Vries (1993), where understanding the individual's thoughts and motivations of the successor is crucial for the succession process. Nevertheless, socialization is rarely used to understand the succession process.

The mutual role adjustment process is the third and probably the best-known theory of leadership succession as perceived in the literature (Handler, 1994; Dyck et al., 2002; Muskat and Zehrer, 2017). The central aspect here is that “(. . .) one can conceptualize each phase of the succession process as being associated with particular role behaviour on the part of the founder or next-generation family member, and the transition from one phase to another as a transition in role behaviour" (Handler, 1994, p. 135). The model assumes that the predecessor and the successor can adjust to the changing nature of their role in the family firm. Thus, the more time they need to become familiar with the new role, the more delayed the overall succession process is.

However, none of these approaches can help us understand and explain the role of communication in the succession process. Thus, our project uses Relational leadership theory (Follett, 1949) as the foundation for this study. The core characteristic of relational leadership is the embedding of authority into each role, based on the knowledge associated with it (Fletcher, 2007). It is a process of reciprocal interrelating through which the expertise held by different participants interconnects, creating a more holistic perspective that is integrative rather than additive (Lipman-Blumen, 1992). Relational leadership requires communicating the interpenetration of expertise among others, which, in turn, requires communication skills to build relationships among others (Lipman-Blumen, 1992; Uhl-Bien, 2006). Leadership succession in family businesses requires a lot of interaction and communication between the parties involved (Handler, 1994; Morris et al., 1996). However, we know very little about how communication dynamics can influence the succession process, the challenges and opportunities that members of different generations in a family firm can face, and how they manage these challenges to facilitate the transition of leadership from one generation to the next (Botero et al., 2013; Michael-Tsabari and Weiss, 2015). Thus, in this project, we use relational leadership theory to explore intergenerational communication and succession.

\section{The role of communication in the leadership succession process}

Communication is core to successful succession and helps to deal with conflicts among business families (Lansberg, 1988; Nordqvist et al., 2009) since it involves the discussion of ideas, giving feedback, as well as intergenerational learning (Handler, 1991; McKee et al., 2014; Grossmann and Schlippe, 2015). Especially in leadership transition, open and transparent communication between successor and predecessors plays a highly important role. Getting it "wrong" can threaten the succession plan and put the family firm at risk of internal conflict and disengagement (Schulze et al., 2003).

Several family business scholars (i.e. Davis and Tagiuri, 1989; Morris et al., 1997), explain the importance and relevance of good communication between predecessor and successor and elaborate that poor communication results in a lack of trust and conflict, which could make succession problematic. Complementing this idea, Saan et al. (2018) show that communication of the succession decision, comprising the transfer date and postsuccession roles to all key stakeholders, affect the succession process and the success of the transfer. Sharma et al. (2003) also suggest that understanding the role of communication in succession is valuable. Finally, Blumentritt et al. (2012) and Michael-Tsabari and Weiss (2015) both show that deficient communication leads to disagreements and clashes between the founder and the successor, systematically harming family harmony. However, a review of the family business literature identified only four studies that included succession and communication in their title or abstract (Botero et al., 2013). 
In family firms, succession often involves leadership changes between members of different generations of the business family (Bertrand and Schoar, 2006). Given that each generation of a business family has underlying beliefs that characterize the family itself and the norms for the involvement of family members in business (Hoy and Sharma, 2010; Sorenson et al., 2013), communication may be highly complex. Communication is even further complicated by the fact that individuals from different generations differ in their expectations about what to say and how to say it (Lee et al., 2003; Efendioglu and Muscat, 2009). This can create additional challenges during the succession process. In an attempt to understand these challenges, Leiß and Zehrer (2018) developed the model of intergenerational negotiation for business family succession. For reducing complexity, the model is based on four factors characterizing intergenerational communication: time, personal characteristics, institutional factors, and societal aspects. With regard to time, an uncommunicated leadership succession might cause conflicts between successor and predecessor since the leadership process heavily builds on the progression of discussions, negotiations, decisions and implementation of solutions among the actors involved (Zehrer and Haslwanter, 2010). With regard to the personal dimension, we find that the old and young generations have different communication behaviors given their diverse experience and knowledge (Westhead et al., 2001), which might result in conflicts. Moreover, the emotional disengagement and shift from the old to the young generation can also have conflict potential. Institution-wise, communication within the business family boosts the reputation, credibility and status of the family firm and makes is necessary to jointly build social networks and communicate strategic alliances (Gallo and García-Pont, 1996; Witt, 2004; Fernández and Nieto, 2005). With regard to society, trends and other effects have shaped the perception of work, where the family no longer serves as a functional entity (Bertram, 2002).

Our model is consistent with the inferential model of family communication. In communication literature, Koerner and Fitzpatrick (2002) developed a theory of family communication referring to the so-called "inferential model" based on the assumption that "many, perhaps most, symbols are fundamentally ambiguous" (Sperber and Wilson, 1986) and have to be recognized and interpreted by means of complex cognitive processes. The interpretation depends on "the ability to make inferences about the intentions behind the use of a symbol" (influenced by, e.g. culture, relationships, individual preferences, etc.). Communication is understood as a process within a social unit (the family) and between cognitive units (individual family members). As a consequence, it is marked by intersubjectivity ("sharing of cognitions") and interactivity ("degree to which symbol creation and interpretation are linked"). This idea is complemented by the work of Schrodt (2005) who developed the circumplex model of marital and family systems and stated that families function in terms of cohesiveness (emotional bonding), flexibility (with regard to leadership, role relationships and relationship rules) and communication (the dynamic component that aids or hinders family movement along the two other dimensions), which shows how family communication schemata (i.e. expressiveness, structural traditionalism and conflict avoidance) contribute to family functioning. However, when exploring business families, it is also important to use the socio-constructionist concept of communication proposed by Luhmann (2011) and his systemic theory. This approach enables us to consider additional elements such as time, institution (the firm), and context, to complement the family system.

The model of intergenerational communication by Leiß and Zehrer (2018) is based on four dimensions of intergenerational communication and includes four distinctive types of communication of business families in the succession process: Authoritarian Protection, Ambivalent Entanglement, Independent Reorientation and Co-Evolutionary Development (see Figure 1 and Table 1). The axes are divided into a relationship axis and an institutional axis that can be related to the work of Koerner and Fitzpatrick (2002). The relationship axis 


\section{$\mathrm{CCIJ}$ 25,3}

Figure 1.

Model of

transgenerational

negotiation (Leiß, 2014)

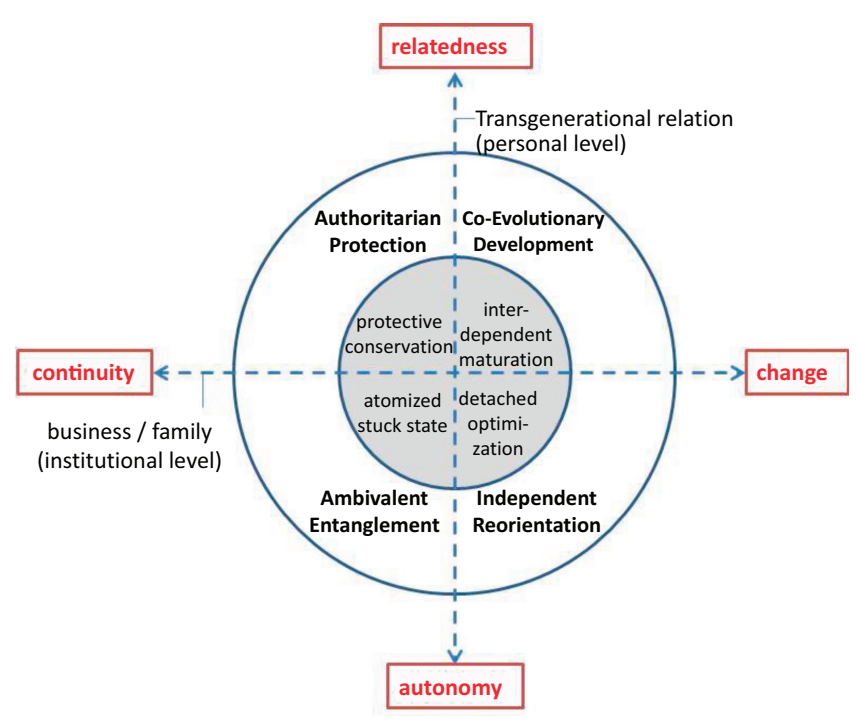

Table 1.

Characteristics of modes of transgenerational negotiation (Leiß, 2014)

\section{Authoritarian protection}

(1) Family is marked by a patriarchal structure

(2) Father is the decision-maker

(3) Successor spends some learning and journeyman years outside the family business

(4) Official power switch

(5) Conserving and expanding of buildings import

(6) Immaterial values (reliability, continuity, loyalty) prevail

Ambivalent entanglement

(1) The succession process is not planned

(2) The unlimited phase of cohabitation

(3) Potential successor undergoes the required training after oscillating between succession and nonsuccession

(4) Symbiotic relationships, double binds, traumata experiences, as well as a lack of negotiation

(5) Little to no innovation and integration of new family members difficult
Coevolutionary development

(1) High degree of generativity with the children, emotional interconnectedness and parents serving as role models

(2) The long phase of fading in and out (3) transgenerational relationship based on cooperation and communication, as well as mutual appreciation and recognition

(3) Family serves as a stabilizing element open to deal with the unknown

\section{Independent reorientation}

(1) Open approach to succession

(2) The main objective is to increase the individuals' room for maneuver / abrupt power switch

(3) Economic independence and survival of the firm are the focus

(4) Lack of knowledge transfer, risk of unexpected social death of predecessor

leads from relatedness to autonomy, while Koerner and Fitzpatrick (2002) talk about the conversation orientation (the degree to which families create a climate of unrestrained interaction). Likewise, the institutional axis from continuity versus change is referred to as conformity orientation (the degree to which family communication stresses a climate of homogeneity of attitudes, values and beliefs) in the work of Koerner and Fitzpatrick (2002). Our paradoxes are also congruent with the work of Pitts et al. (2009) who, based on relational dialectics theory (Baxter and Montgomery, 1996), differentiate among three dialectical 
tensions of competing voices-openness versus closedness, autonomy versus Intergenerational interdependence and certainty versus uncertainty.

In the mode of Authoritarian Protection, the predecessor acts as a patriarch and takes decisions on his own; thus, communication among the business family is rather limited. This is congruent with the work of Koerner and Fitzpatrick (2002), who differentiate four family types, of which one is "consensual", i.e. high in conversation and conformity orientation. When families reconstruct succession according to the second type, Ambivalent Entanglement, there is no plan for succession in place, resulting in an unlimited phase of communication barriers cohabitation and "stuck state," often accompanied by a lack of communication and negotiation. This equals the family type "protective" in Koerner and Fitzpatrick's work, i.e. low on conversation orientation but high on conformity orientation (Koerner and Fitzpatrick, 2002). The mode of Independent Reorientation is characterized by an open approach to succession, including a quite open and transparent way of communicating, giving the successor increased room for maneuver. This is congruent with the family type "laissez-faire" of Koerner and Fitzpatrick (2002), i.e. low in both conversation and conformity orientation. Business families, who understand the succession process as Co-Evolutionary Development, have a long phase of fading in and out and ground the transition on cooperation and communication, as well as mutual appreciation and recognition; this phase is equal to the family type "pluralism" in the inferential model of Koerner and Fitzpatrick (2002), i.e. high in conversation but low in conformity orientation (Koerner and Fitzpatrick, 2002). This type is also congruent with the "partnership" framework for nurturing potential successors identified by Kaplan et al. (2009).

The "ideal" succession process includes three phases of negotiation: phase 1: transgenerational transmission, phase 2: independent acquisition, and finally, phase 3 : interdependent development of the family-firm heritage (Leiß and Zehrer, 2018).

Building on previous work on transgenerational negotiation, succession, and communication, we used an in-depth to explore the following research questions:

$R Q 1$. What are the barriers/pitfalls in intergenerational communication during the succession process?

RQ2. Which intergenerational communication dynamics exist during the succession process?

RQ3. How can succession-related communication problems in business families be solved?

\begin{abstract}
Methods
Research paradigm

The main goal of this project is to gain deeper insights into how business families create and experience communication dynamics in leadership succession, and at the same time, to develop supporting actions resulting in positive change for them. As a consequence, we follow a qualitative action research approach based on a single real-life case study. Case study research is advocated as a valid research strategy, e.g. in marketing (Bonoma, 1985), operations management (McCutcheon and Meredith, 1993), management information systems (Benbasat et al., 1987), and strategy (Mintzberg, 1979; Eisenhardt, 1989; Larsson, 1993). Most of these authors consider case study a useful research strategy (1) when the topic is broad and highly complex, (2) when there are not a lot of theories available, and (3) when "context" is very important. Thus, to discuss intergenerational communication patterns in business families, we apply a case study approach in a single-family firm context. By using an action research approach, we want to initiate change and improvement through a better
\end{abstract}


$\mathrm{CCIJ}$

25,3

522

understanding of the unique communication problems that affect business families (Poza et al., 1998).

\section{Case description}

The business family owns a four-star hotel, which was founded by Ady and Jessica in 1965 and is nestled in a famous year-round destination amidst the Tyrolean Alps in Austria. The core target market of the destination is the nuclear family, consisting of parents and kids of all ages. Besides nuclear families, the destination also wants to attract extended families. The core branding and positioning of the destination is to provide exciting mountain experiences for families at a service excellence level. In 2017, the hotel achieved revenues of $€ 14$ Mio. Altogether, it has 134 employees and five division managers. The employee fluctuation is below $20 \%$, a good value in the hospitality and tourism industry, given the general struggle of the industry to attract staff. The main target market is Germany, followed by Austria, Switzerland and the United Kingdom. In 2016 and 2017, the owners made high investments ( $€ 13$ Mio. investment sum), refurbished rooms and the restaurant and built a whole new outdoor wellness area. Figure 2 portrays the family tree.

The first generation Ady and Jessica handed over the business to their daughter Patricia in 1982, who, together with her husband Perry, has run the hotel ever since. In 1982, the business was very small, with a staff of six employees. In 1997, Patricia and Perry had the chance to take over another hotel in the same village, which also specialized in families, and took this opportunity. Since then, the family owns two four-star hotels focusing on families with small children. While one hotel is managed by an external director (i.e. nonfamily), the other is managed by Perry (61) as the hotel director. Patricia (57) takes care of the reservation and bookings for both hotels. However, she has felt a great desire for an improved work-lifebalance in the last couple of years.

Patricia and Perry have two sons, Charles (33) and Peter (27), who are both willing to take over the family business. The older son Charles has been working in the family business for five years together with his wife Susan (32) from Germany, who runs the reception. Both of them have been educated in hospitality and tourism in a highly renowned hotel management school in Switzerland. They have two daughters aged one and three. The younger son Peter studied financial management in the United States and Spain, where he met Olivia (30) from Chile, who studied marketing management and worked in marketing for big companies over the last years. Peter has worked at multinational companies in Geneva, Switzerland, for the last few years, and both Peter and Olivia have not been involved in the family hotel so far. Their plan to marry and move to the Alpine village in September 2017 was a challenge since both were inexperienced in the hotel industry. In addition, Olivia does not speak German. Although she was born into a family business in Chile herself, she decided not to work there to avoid the everyday conflicts she could observe amongst her relatives. Due to unsolved and increasingly stressful communication problems within the business family, Patricia contacted us for support in the leadership succession process.

Figure 2.

Family tree-main actors in bold letters, conflict parties in grey boxes

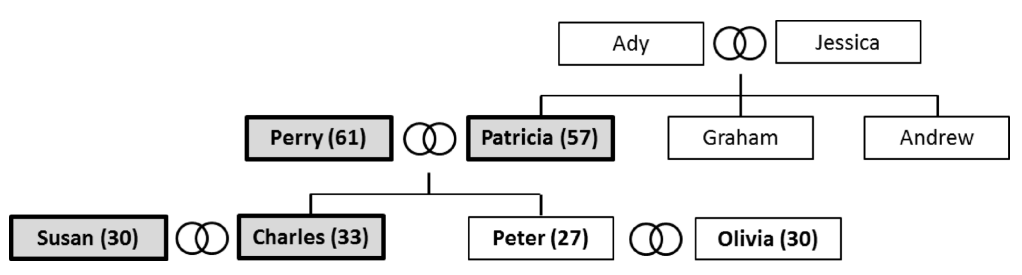


Procedure

The action research method was developed by Lewin (1946) to study social psychology and a form of experimental inquiry within the framework of field theory (Eden and Huxham, 1996). We decided that an action research approach would serve the requirements of this case best since it aims at producing practical knowledge and creating solutions to complex problems like succession and allows us to make use of various intervention practices combining research, action and participation at the same time (Bradbury and Reason, 2003; Coghlan and Brannik, 2014; James et al., 2012). In action research, quantitative, qualitative or sequential mixed methods can be applied. To understand the subjective perception and interpretation of the business family members, we focused on qualitative methods. As shown in Figure 1, the overall research process follows a circular logic, including discovery and understanding, planning and taking measurable actions and reflection/evaluation (James et al., 2012).

The discovery stage basically consisted of further research on the problem and contracting via phone. The second step, measurable actions, included three elements. First, we interviewed each family member individually with narrative interviews lasting between 1.5 and $3 \mathrm{~h}$. The main objective of this intervention was to understand the individual perspective of each family member. Based on the reflective analysis of the interviews, we set up a couple of workshops lasting up to four hours to offer the possibility of developing a shared vision amongst the spouses. Third, we hosted a $5 \mathrm{~h}$ business family workshop with four family members (predecessors and successors already working in the hotel) with the intention to exchange individual perspectives about the status quo of succession, define a shared vision, as well as critical themes and agree on the further solution and communication process, including the development of family governance and a concrete succession plan.

Over the entire research process that lasted one year, from January to December 2017, data was collected using reflective journals, field notes and observation protocols (James et al., 2012). For data analysis, the evaluation method of Smith et al. (1999), which follows a circular strategy and analyses data in creative thought loops, is used. Circular deconstruction, on the one hand, implies that implicit meaning can become visible and, on the other hand, a change of perspective takes place, giving rise to new insights and contributing to answering the research questions (Smith et al., 1999; Deniz and Lincoln, 2000). This paraphrasing and systemic comparison process leads to the emergence of metathemes, which are presented in the findings section below.

\section{Research findings}

The first aspect that we wanted to understand was what were the barriers and pitfalls that the business family faces in their intergenerational communication. Based on our observations, the communication strategy and patterns of this case largely represent the Ambivalent Entanglement communication type. There are several characteristics that show this. First, the succession from Perry and Patricia to the next generation is not planned at all, i.e. there is no concrete time plan with regard to the transfer of power. This results in an unlimited phase of cohabitation with the two generations working side by side without a clear perspective about the future. Therefore, intergenerational relationships are characterized by a lack of negotiation, which results in one-sided decision-making. Second, as a consequence of the unsolved ambivalences and conflicts, the potential successor Charles is oscillating between succeeding and leaving. With regard to the organizational development of the hotel, there is little innovation. For example, Perry still processes all incoming invoices manually. This leads to delays in payment, which can result in conflicts for the family. Third, the integration of new family members (Susan and Olivia) seems to be difficult, given the socialization and background of both daughters-in-law, which resulted in different value propositions with regard to work-life-balance, the professionalism of work, family support,
Intergenerational communication barriers 
CCIJ

25,3

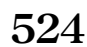

etc. Forth, communication is marked by a low level of self-awareness and empathy, resulting in a coping strategy between avoiding and competing (Thomas and Kilmann, 2010), which highly impairs a smooth transition from one generation to the next. Thus, we found the following communication barriers: no discussion between generations regarding the plans they are creating, no explicitness of information, no participation of other generations, and thus, focus on one-way communication, no clarity of message and goals.

The second question that we wanted to address was the intergenerational communication dynamics existing during the succession process to provide an answer as to how the communication occurs between intergenerational members. Our observations indicate that there were different communication dynamics that occurred: Within the predecessor generation, between predecessor and successor, and within the successor generation.

Within the predecessor generation, the main challenge for Perry is the transfer of power and responsibility, which is impaired by his enormous sense of duty to trustfully manage his wife's heritage and property. In addition, he suffers from the burden of the last building project financed by a huge bank loan, as well as from an inadequate old-age pension. Perry also has no plan as to who would take over the hotel and when and how his life would look like without working there every day. His main motives are autonomy, individuality and independence, expressed as "fear of losing my independence", "niche apart from the mainstream" and "active shaping of the future". In the couple workshop, it becomes clear that Perry and his wife do not have a shared vision of how to organize their future life. For Patricia, the most important concern is to find a successor for the reservation office since she wants to retire from her operational duties during the year. Her main needs include continuity, reliability and commitment; her motives are "obligation towards the family, staff and society", to "maintain and increase the family heritage" and "success-financial and personal". Both in the interview and the workshops, she utters her desire for peace, recreation, harmony and peace within the family, privacy and retreat from work. This suggests that the communication dynamics between the members of this generation are characterized by very little sharing regarding what should be their goals and roles during this succession process. This lack of clarity of goals and roles then affect the messages that they send to the successor generation and how this information is received and interpreted by the younger generation.

Regarding the dynamics between predecessor and successor generations, there seem to be two perspectives of what occurs in the communication between generations. The predecessor generation perceives that their exchanges with the successor generation should center around the responsibility that the successors have for the legacy of the family, the obligation to their employees, and the protection of the predecessors' financial future. Thus, all of the interactions reflect this type of dynamics. For example, in the couple workshops, Perry speaks about himself as a "judge" standing between Patricia and his sons in his effort to guarantee their private retirement irrespective of the new debts. Communication between the predecessor and the successor generation was marked by little empathy, missing trust, mutual accusations and biases. The intergenerational communication pattern thus was conflict avoiding, largely in written form and scarce.

From the successor's perspective, the older son Charles struggles with the way his father treats him in the business. He complains about the missing rules and regulations with regard to his responsibilities and competencies as a hotel director. He does not agree with the way decisions are made by his father, who practices a rather authoritarian leadership style. Charles is longing for appreciation and development, support and trust, contact and relatedness and a relational leadership style. His motives for engaging in the family firm comprise "enjoy working in the hotel business", "see people laughing and fulfil their wishes", "work with employees and get to know them", "develop myself" and "develop the hotel". His wife Susan also regards the missing workplace and job descriptions in a company with more than one hundred employees as a source of constant trouble. For her, reliability and belonging 
are vital needs expressed as "grateful for security and support", "bound by tradition", "success of the family" and "professional honour-dream job". When Charles and Susan got married in the village, the father already announced handing over the business to them after their marriage in front of many people from the village. Given the promise at their marriage, which had not come true, both Charles and Susan do not believe in a succession plan any longer. Between 2016 and 2017, Charles wanted to withdraw from succeeding three times. Personal conversation and communication have become rare, especially between Perry and Charles: they have started to communicate with each other, mainly via email.

Charles and his brother Peter are not very close, which originates in their early education years, where both of them were in residential schools in another province of Austria. Further, they are very different characters. While Charles is a very socially embedded person who engages in the community life (voluntary fire brigade, village clubs and associations), Peter is a sports enthusiast and mostly a unilateral person. Given that Peter has had diabetes from early childhood on, Charles has the impression that Peter has always been treated differently or even better by his parents; he envies Peter in some regard. In addition, Charles envisages Peter as a threat when Peter enters the family business since Charles has been the only son working in the family firm so far while Peter has been employed in a completely different sector.

The needs and desires of both generations are only partially compatible, which explains the succession dynamics. For Perry, exiting from his management role is connected with enormous fears, leading to paradox behavior and communicative patterns such as: "I need competent successors but I do not think they are capable of anything" or "succession will only work with a sharp cut, but I do not want to commit myself as to when I will hand over the firm". Charles, however, hates his father interfering with everyday managerial tasks, and at the same time wants to get support and recognition.

With regard to the third research question on how succession-related communication problems in business families can be solved, we identified the following ways to overcome the succession iceberg. In order to unfreeze the "stuck state" of Ambivalent Entanglement the business family found themselves in, we helped them to "translate" all fact-oriented succession issues, such as organizational structure and regulations, into corresponding motives and needs, helping them to get in closer contact with their emotional barriers and communication hindrances, which is a prerequisite for any change. Thus, the workshops with the couples and the business family allowed us to deduce a picture of a case-specific succession "iceberg" (Satir et al., 2008). The iceberg phenomenon follows a system thinking approach that tries to understand how various levels within a system influence each other. The upper, conscious level accounts for approximately $10 \%$ of the intergenerational communication and includes various hard facts that are tangible, logical, rational and materialistic. The lower, subconscious level steers approximately $90 \%$ of intergenerational communication and consists of soft factors that are invisible, intangible and inward such as feelings, emotions, relations, culture, trust or empathy (Goodman, 2002). To overcome these challenges, the family needs to have a clear structure, including distinct goals helping the business family understand what they want to do and how they need to approach the process.

\section{Reflection and learnings}

One of the major goals of the action research process underlying this case was to take interventions, which increased the consciousness, as well as the personal and social competencies of the business family in their leadership succession. The methodological approach we applied was highly resource- and solution-oriented, thus leaving little space for "looking back" and working on past injuries. This resulted in an emotional crisis initiated by Charles, who, during the family workshop, felt triggered by a side-remark of his father and 
CCIJ

25,3

left the room in a rage. His outburst highly irritated Patricia and Susan, who started crying and was very concerned that her husband would leave the company. Finally, we asked Perry to look for his son, apologize and ask him to come back. Since, at that point, all the members of the business family were exhausted, we finished the workshop after a short feedback and agreed to continue the process within the next few weeks. Yet, although a considerable number of succession-related problems had not been solved, the family did not want to engage in further interventions afterwards.

Our main findings from the evaluation of our interventions are as follows:

(1) Goal clarity is an important prerequisite to facilitate the communication process. The business family involved should be clearly informed about the principles of conflict resolution and change, including their own role and commitment to participate in interventions and reflect the outcome regularly.

(2) "Untangling" the business family's communication strategies need regular work over a longer period since behavior is closely linked to basic attitudes, assumptions and beliefs that first of all have to be made tangible.

(3) Business families stuck in Ambivalent Entanglement might, therefore, require a multimethod research approach aiming at (1) consciousness-raising, (2) conflict resolution and (3) development of new structures and processes. For consciousnessraising, it might be helpful to include measurable actions like a quantitative survey of the firm's culture and discuss the results with the business family. The outcome might increase their willingness to engage in mediation-based conflict resolution settings, enhancing self-awareness and mutual understanding with regard to the lower level of the succession iceberg. Both process steps can be seen as the prerequisite for developing a shared vision and a clear succession framework with the corresponding milestones.

(4) Following a circular intervention approach, as suggested here, it seems to be highly reasonable since it leaves enough flexibility to constantly adapt the process depending on the outcome of the actions taken so far.

(5) Researchers require a large set of methodological, personal and social competences, including self-reflection and tolerance of ambiguity, to deal with the unknown inherent in this research approach. The role of the action researcher then is that of a facilitator, not of an advocate for any business family member.

\section{Conclusions and implications}

The purpose of this paper was to explore the pertinent issues of intergenerational communication in business families during their leadership succession period. The results from this exploratory study provide an initial picture of communication issues and dynamics in family firm succession. First, based on the observations from this study, it seems that barriers and pitfalls hinder intergenerational communication among the business family in transition, which is congruent to earlier studies (Davis and Tagiuri, 1989; Weigel and Weigel, 1993; Morris et al., 1997). Second, we showed that poor communication between predecessor and successor results in a lack of trust and conflict, which makes succession problematic, leading to disagreements and clashes, as well as systematically impacting family harmony (Morris et al., 1997; Blumentritt et al., 2012; Michael-Tsabari and Weiss, 2015; Saan et al., 2018). Third, our results also provide some initial empirical support for the conceptual work of Leiß (2014) and Leiß and Zehrer (2018) by applying the dynamic succession model using the singleaction research approach based on a single real-life case study. Our findings give experts a 
comprehensive insight into the barriers and pitfalls caused by Ambivalent Entanglement between predecessors and successors in business families. They also underpin the rationale that leadership succession is grounded on various communication patterns that are dynamic over time, supporting former findings (Fernández and Nieto, 2005; Nordqvist et al., 2009; Zehrer and Haslwanter, 2010). Findings are also congruent with existing models in communication behavior, such as the inferential model by Koerner and Fitzpatrick (2002), the circumplex model of family functioning (Schrodt, 2005), and the relational dialectics theory by Pitts et al. (2009).

Our findings are also consistent with previous work on communication in family firm succession (Michael-Tsabari and Weiss, 2015; Weigel and Weigel, 1993). Weigel and Weigel (1993) found that the younger generation experienced significantly more intergenerational communication problems, and thus, were less satisfied than the predecessor generation due to a lack of communication competences and resources. Michael-Tsabari and Weiss (2015) incorporated game theory to gain insight about communication traps during the transition process and also revealed that structure is core to overcome inadequate communication patterns. Thus, this project deepens our knowledge in understanding the role of communication in leadership succession and reveals several implications for theory and research.

In line with previous research (Lansberg, 1988; Nordqvist et al., 2009), we saw that communication and resulting interactions among predecessors and successors are core to leadership succession among generations (Handler, 1991; McKee et al., 2014; Grossmann and Schlippe, 2015). Since successors highly depend on knowledge transfer, as well as the transfer of culture and values, ambivalences might decrease their willingness to take over the family firm or even procrastinate the whole process. Moreover, our results are also consistent with the importance of having some degree of professionalization within the organization and having clear goals within the family and the business.

From a methodological point of view, we found that action research is a fruitful way of investigating the change introduced in a business family during the transition time of leadership succession and that it thus has practical implications for business families. The communication strategies and patterns in the underlying case study were highly dependent upon the personal interactions among the parties involved; this, on the one hand, could be seen as an asset for the business family and its future development, on the other hand, the family members often also hit the roof, which could particularly be observed in the family workshop. However, sound knowledge of different communication patterns might raise awareness about and prevent conflicts during leadership succession and thus function as a strategic advantage for business families.

Given the large number of business families in transition, our study shows the beneficial effects action research might have on business families' communication behavior. We also reveal that clear and shared goals during times of succession are a vital prerequisite for a smooth transition. Thus, although our findings cannot be generalized at large, we make a contribution to communication literature in the context of family firms by addressing a theoretical issue as to how successors and predecessors communicate during the leadership succession process and show ways to solve intergenerational communication conflicts based on a single case study. The findings might help other business families to understand the value of action research for such underlying challenges and decrease communication barriers. Finally, this is one of the few studies to have addressed intergenerational communication in business families using an action research approach.

Despite the findings of this paper, there are several limitations that we need to point out. In our case, our interventions helped the business family in understanding the need for change; however, the ending remained open after the last business family workshop, which means the failure or success to create change among the business family remains open. Thus, future research should focus on longitudinal studies, where the researchers accompany a business 
CCIJ

25,3

528

family over a longer period of time to evaluate their communication patterns during the transition process. Second, there might be an ethical dilemma since, as investigators in an action research setting characterized by an integral involvement, we might have been too subjective over the period working with the business family. Because of this, future research should also make use of accompanying methods, such as focus groups or individual interviews. Third, given our focus on the hospitality context, the results might not generalize to other business families since the context might be different. Thus, it would be useful for future research to explore our ideas in different industries to see how these results replicate and generalize into other contexts. Fourth, we used a single case study, a method, which is criticized and questioned with regard to the validity and reliability of the results as findings are often unique to the specific research and may thus not be generalized to the population at large. Of course, in future research, a multiple case study approach would have improved the external validity and generalizability of our findings. Additionally, the use of other methodological approaches could enhance our understanding of intergenerational communication during succession.

This exploratory study is one of the few to explore the pertinent issues of intergenerational communication in business families during their leadership succession period and provides an initial picture of communication issues and dynamics in family firm succession. By applying action research to a real case, we have deliberately followed an unconventional and innovative methodological approach that is marked by a highly flexible procedure. Our intention in openly addressing its benefits and limitations may inspire other researchers to consider action research as a valuable approach for solving practical projects since its interventions have the potential to not only produce data for researchers but also real-life solutions for businesses.

\section{References}

Ambrose, D.M. (1983), "Transfer of the family-owned business", Journal of Small Business Management, Vol. 21 No. 1, pp. 49-56.

Barach, J.A., Ganitsky, J.B., Carson, J.A. and Donchin, B.A. (1988), "Entry of the next generation: strategic challenge for family business", Journal of Small Business Management, Vol. 26 No. 1, pp. 49-56.

Barnes, L.B. and Hershon, S.A. (1976), "Transferring power in the family business", Harvard Business Review, Vol. 54 No. 4, pp. 105-114.

Baxter, L.A. and Montgomery, B.M. (1996), The Guilford Communication Series. Relating: Dialogues and Dialectics, Guilford Press, New York.

Benbasat, I., Goldstein, D.K. and Mead, M. (1987), "The case research strategy in studies of information systems", MIS Quarterly, Vol. 11 No. 3, pp. 369-386.

Bertram, H. (2002), "Die multilokale Mehrgenerationenfamilie. Von der neolokalen Gattenfamilie zur multilokalen Mehrgenerationenfamilie”, Berliner Journal für Soziologie, Vol. 12 No. 4, pp. 517-529.

Bertrand, M. and Schoar, A. (2006), "The role of family in family firms", The Journal of Economic Perspectives, Vol. 20 No. 2, pp. 73-96.

Bigliardi, B. and Dormio, A. (2009), "Successful generational change in family business", Measuring Business Excellence, Vol. 13 No. 2, pp. 44-50.

Birley, S. (1986), "Succession in the family firm: the inheritor's view", Journal of Small Business Management, Vol. 24 No. 2, pp. 36-43.

Birley, S. (2002), "Attitudes of owner-managers' children towards family and business issues", Entrepreneurship: Theory and Practice, Vol. 26 No. 3, pp. 5-19.

Blumentritt, T., Mathews, T. and Marchisio, G. (2012), "Game theory and family business succession: an introduction”, Family Business Review, Vol. 26 No. 1, pp. 51-67.

Bonoma, T.V. (1985), "Case research in marketing: opportunities, problems, and a process", Journal of Marketing Research, Vol. 22 No. 2, pp. 199-208. 
Botero, I.A., Thomas, J., Graves, Ch. and Fediuk, T.A. (2013), "Understanding multiple family firm identities: an exploration of the communicated identity in official websites", Journal of Family Business Strategy, Vol. 4 No. 1, pp. 12-21.

Bracci, E. and Vagnoni, E. (2011), "Understanding small family business succession in a knowledge management perspective”, The IUP Journal of Knowledge Management, Vol. 9 No. 1, pp. 7-26.

Bradbury, H. and Reason, P. (2003), "Action research: an opportunity for revitalizing research purpose and practices", Qualitative Social Work, Vol. 2 No. 2, pp. 173-83.

Cabrera-Suárez, K., de Saá-Pérez, P. and García-Almeida, D. (2001), "The succession process from a

Intergenerational communication barriers resource- and knowledge-based view of the family firm”, Family Business Review, Vol. 14 No. 1, pp. 37-46.

Cabrera-Suárez, K. (2005), "Leadership transfer and the successor's development in the family firm", The Leadership Quarterly, Vol. 16 No. 1, pp. 71-96.

Chrisman, J.J., Steier, L.P. and Chua, J.H. (2008), "Toward a theoretical basis for understanding the dynamics of strategic performance in family firms", Entrepreneurship: Theory and Practice, Vol. 32 No. 6, pp. 935-947.

Churchill, N.C. and Hatten, K.J. (1987), "Non-market-based transfers of wealth and power: a research framework for family businesses", American Journal of Small Business, Vol. 11 No. 3, pp. 51-64.

Coghlan, D. and Brannik, T. (2014), Doing Action Research in Your Own Organization, SAGE Publications, London.

Daspit, J.J., Holt, D.T., Chrisman, J.J. and Long, R.G. (2015), "Examining family firm succession from a social exchange perspective: a multiphase, multistakeholder review", Family Business Review, Vol. 29 No. 3, pp. 44-64.

Davis, J.A. and Klein, S. (2005), "Succession", in Kenyon-Rouvinez, D. and Ward, J.L. (Eds), Family Business Key Issues, Palgrave Macmillan, Basingstoke, pp. 59-72.

Davis, J.A. and Tagiuri, R. (1989), "The influence of life-stage on incumbent-son work relationships in family companies", Family Business Review, Vol. 2 No. 1, pp. 47-74.

Davis, S.M. (1968), "Entrepreneurial succession”, Administrative Science Quarterly, Vol. 13 No. 3, pp. $402-416$.

De Massis, A., Chua, J.H. and Chrisman, J.J. (2008), "Factors preventing intra-family succession", Family Business Review, Vol. 21 No. 2, pp. 183-199.

Denzin, N.K. and Lincoln, Y.S. (2000), Handbook of Qualitative Research, Sage, Newberry Park, CA.

Drakopoulou-Dodd, S., Anderson, A. and Jack, S. (2013), "Being in time and the family owned firm", Scandinavian Journal of Management, Vol. 29 No. 1, pp. 35-47.

Duh, M. (2014), "Family business succession as knowledge creation process", Kybernetes, Vol. 43 No. 5, pp. 699-714.

Durst, S. and Wilhelm, S. (2012), "Knowledge management and succession planning in SMEs", Journal of Knowledge Management, Vol. 16 No. 4, pp. 637-649.

Dyck, B., Mauws, M., Starke, F.A. and Mischke, G.A. (2002), "Passing the baton: the importance of sequence, timing, technique and communication in executive succession", Journal of Business Venturing, Vol. 17 No. 2, pp. 143-162.

Eden, C. and Huxham, C. (1996), "Action research for management research", British Journal of Management, Vol. 7 No. 1, pp. 75-86.

Efendioglu, A.M. and Mucat, E. (2009), "Internal disruptions in family business succession: death, divorce, and disability", The Journal of Industrial Relations and Human Resources, Vol. 11 No. 1, pp. 17-31.

Eisenhardt, K.M. (1989), "Building theories from case study research", Academy of Management Review, Vol. 14 No. 4, pp. 532-550. 
CCIJ

25,3

Fernández, Z. and Nieto, M.J. (2005), "Internationalization strategy of small and medium-sized family businesses: some influential factors", Family Business Review, Vol. 18 No. 1 , pp. 77-89.

Fitzpatrick, M.A. (2004), "Family communication patterns theory: observations on its development and application", Journal of Family Communication, Vol. 4 Nos 3-4, pp. 167-179.

Fletcher, J.K. (2007), "Leadership, power, and positive relationships", in Dutton, J.E. and Ragins, B.R. (Eds), Exploring Positive Relationships at Work: Building a Theoretical and Research Foundation, Psychology Press, New York, pp. 347-371.

Follett, M.P. (1949), Freedom and Co-ordination: Lectures in Business Organization by Mary Parker Follett, Management Publications Trust, London.

Fox, M.A., Nilakant, V. and Hamilton, R.T. (1996), "Managing succession in family-owned businesses", International Small Business Journal, Vol. 15 No. 1, pp. 15-25.

Gallo, M.A. and García-Pont, C. (1996), "Important factors in family business internationalization", Family Business Review, Vol. 38 No. 4, pp. 15-47.

Gbadegeshin, S.A. (2013), "Awareness of "ownership succession" and family business continuity", International Journal of Business and Management Invention, Vol. 2 No. 9, pp. 72-87.

Giarmarco, J. (2012), “The three levels of family business succession planning”, Journal of Financial Service Professionals, Vol. 66 No. 2, pp. 59-69.

Goodman, M. (2002), The Iceberg Model, Innovation Associates Organizational Learning, Hopkinton, MA, available at: http://www.ascd.org/ASCD/pdf/journals/ed_lead/el200910_kohm_iceberg.pdf.

Griffeth, R.W., Allen, D.G. and Barrett, R. (2006), "Integration of family-owned business succession with turnover and life cycle models: development of a successor retention process model", Human Resource Management Review, Vol. 16 No. 4, pp. 490-507.

Grossmann, S. and von Schlippe, A. (2015), "Family businesses: fertile environments for conflict", Journal of Family Business Management, Vol. 5 No. 2, pp. 294-314.

Haag, K. (2012), "Rethinking family business succession: from a problem to solve to an ongoing practice”, Jönköping International Business School, Jönköping, available at: http://hj.diva-portal. org/smash/record.jsf?pid= diva2:545887 (accessed 1 August 2018).

Halter, F.A. (2009), Familienunternehmen im Nachfolgeprozess: Die Emotionen des Unternehmers, Eul Verlag, Lohmar.

Handler, W.C. (1989), "Methodological issues and considerations in studying family business", Family Business Review, Vol. 2 No. 3, pp. 257-276.

Handler, W.C. (1990), "Succession in family firms: a mutual role adjustment between owner-manager and next-generation family members", Entrepreneurship: Theory and Practice, Vol. 15 No. 3, pp. 37-51.

Handler, W.C. (1991), "Key interpersonal relationships of next-generation family members in family firms", Journal of Small Business Management, Vol. 9 No. 3, pp. 21-32.

Handler, W.C. (1994), "Succession in family business: a review of the research", Family Business Review, Vol. 7 No. 2, pp. 133-157.

Hoy, F. and Sharma, P. (2010), Entrepreneurial Family Frrms, Pearson Prentice Hall, Upper Saddle River, NJ.

James, E.A., Slater, T. and Bucknam, A. (2012), Action Research for Business, Nonprofit \& Public Administration SAGE Publications, London.

Kaplan, M.S., Nussbaum, J.F., Becker, J.C., Fowler, C. and Pitts, M. (2009), "Communication barriers to family farm succession planning", Journal of Extension, Vol. 47 No. 5, pp. 1-9.

Kets de Vries, M.F.R. (1993), "The dynamics of family controlled firms: the good and the bad news", Organizational Dynamics, Vol. 21 No. 3, pp. 59-71.

Koerner, A.F. and Fitzpatrick, M.A. (2002), "Toward a theory of family communication", Communication Theory, Vol. 12 No. 1, pp. 70-91. 
Lansberg, I.S. (1988), “The succession conspiracy”, Family Business Review, Vol. 1 No. 2, pp. 119-143.

Larsson, R. (1993), "Case survey methodology: quantitative analysis of patterns across case studies", Academy of Management Journal, Vol. 36 No. 6, pp. 1515-1546.

Le Breton-Miller, I., Miller, D. and Steier, L. (2004), "Toward an integrative model of effective FOB succession", Entrepreneurship: Theory and Practice, Vol. 28 No. 4, pp. 305-328.

Lee, K.G., Lim, G.H. and Lim, W.S. (2003), "Family business succession: appropriation risk and choice of successor", Academy of Management Review, Vol. 28 No. 4, pp. 657-666.

Leiß, G. and Zehrer, A. (2018), "Intergenerational communication in family firm succession", Journal of Family Business Management, Vol. 8 No. 1, pp. 75-90.

Leiß, G. (2014), Ich sehe das Ganze als Staffellauf, Intergenerative Aushandlung im Nachfolgeprozess von Unternehmerfamilien, Carl-Auer-Systeme, Heidelberg.

Lewin, K. (1946), “Action research and minority problems”, Journal of Social Issues, Vol. 2 No. 4, pp. 34-46.

Lipman-Blumen, J. (1992), "Connective leadership: female leadership styles in the $21^{\text {st }}$ century workplace”, Sociological Perspectives, Vol. 35 No. 1, pp. 183-203.

Luhmann, N. (2011), Einführung in die Systemtheorie, Carl-Auer-Verlag, Heidelberg.

McCutcheon, D.M. and Meredith, J.R. (1993), "Conducting case study research in operations management", Journal of Operations Management, Vol. 11 No. 3, pp. 239-256.

McKee, D., Madden, T.M., Kellermanns, F.W. and Eddleston, K.A. (2014), "Conflicts in family firms: the good and the bad", in Melin, L., Nordqvist, M. and Sharma, P. (Eds), SAGE Handbook of Family Business, Sage Publications, London, pp. 514-528.

Michael-Tsabari, N. and Weiss, D. (2015), "Communication traps: applying game theory to succession in family firms", Family Business Review, Vol. 28 No. 1, pp. 26-40.

Morris, M.H., Williams, R.W. and Nel, D. (1996), "Factors influencing family business succession", International Journal of Entrepreneurial Behaviour and Research, Vol. 2 No. 3, pp. 68-81.

Morris, M., Williams, R., Allen, J. and Avila, R. (1997), "Correlates of success in family business transitions", Journal of Business Venturing, Vol. 12 No. 5, pp. 385-401.

Motwani, J., Levenburg, N.M. and Schwarz, T.V. (2006), "Succession planning in SMEs: an empirical analysis", International Small Business Journal, Vol. 24 No. 5, pp. 471-495.

Murray, B. (2003), "The succession transition process: a longitudinal perspective", Family Business Review, Vol. 16 No. 1, pp. 17-33.

Muskat, B. and Zehrer, A. (2017), "A power perspective on knowledge transfer in internal succession of small family businesses", Journal of Small Business and Entrepreneurship, Vol. 29 No. 5, pp. 333-350.

Mintzberg, H. (1979), “An emerging strategy of 'direct' research”, Administrative Science Quarterly, Vol. 24 No. 4 , pp. 582-589.

Nordqvist, M., Hall, A. and Melin, L. (2009), "Qualitative research on family businesses: the relevance and usefulness of the interpretive approach", Journal of Management and Organization, Vol. 15 No. 3, pp. 294-308.

Pitts, M.J., Fowler, C., Kaplan, M.S., Nussbaum, J. and Becker, J.C. (2009), "Dialectical tensions underpinning family farm succession planning", Journal of Applied Communication Research, Vol. 37 No. 1, pp. 59-79.

Poza, E.J., Johnson, S. and Alfred, T. (1998), "Changing the family business through action research", Family Business Review, Vol. 11 No. 4, pp. 264-272.

Rubenson, G.C. and Gupta, A.K. (1996), "The initial succession: a contingency model of founder tenure", Entrepreneurship: Theory and Practice, Vol. 21 No. 2, pp. 21-35.

Saan, R., Enu-Kwesi, F. and Nyewie, N.F. (2018), "Factors influencing succession planning for continuity of family-owned businesses in the wa municipality, Ghana", Universal Journal of Management, Vol. 6 No. 5, pp. 165-177. 
CCIJ 25,3

Satir, V., Banmen, J., Gomori, M. and Gerber, J. (2008), The Satir Model: Family Therapy and beyond, Science and Behavior Books, Palo Alto.

Schrodt, P. (2005), "Family communication schemata and the circumplex model of family functioning", Western Journal of Communication, Vol. 69 No. 4, pp. 359-376.

Schulze, W.S., Lubatkin, M.H. and Dino, R.N. (2003), "Exploring the agency consequences of ownership dispersion among inside directors at family firms", Academy of Management Journal, Vol. 46 No. 2, pp. 179-194.

Sharma, P., Chrisman, J.J., Pablo, A.L. and Chua, J.H. (2001), "Determinants of initial satisfaction with the succession process in family firms: a conceptual model", Entrepreneurship: Theory and Practice, Vol. 25 No. 3, pp. 17-35.

Sharma, P., Chrisman, J.J. and Chua, J.H. (2003), "Succession planning as planned behavior: some empirical results", Family Business Review, Vol. 16 No. 1, pp. 1-15.

Smith, J.A., Jarman, M. and Osborn, M. (1999), "Doing interpretative phenomenological analysis", in Murray, M. and Chamberlain, K. (Eds), Qualitative Health Psychology, Sage, London, pp. 218-240.

Sorenson, R.L., Yu, A., Brigham, K.H. and Lumpkin, G.T. (2013), The Landscape of Family Business, Edward Elgar Publishing, Northampton, MA.

Sperber, D. and Wilson, D. (1986), "Beyond speaker's meaning”, Croatian Journal of Philosophy, Vol. 15 No. 44 , pp. 117-149.

Steier, L. (2001), "Next-generation entrepreneurs and succession: an exploratory study of modes and means of managing social capital", Family Business Review, Vol. 14 No. 3, pp. 259-276.

Thomas, K. and Kilmann, R. (2010), "Thomas-kilmann conflict mode instrument profile and interpretive report", available at: https://www.cpp.com/en-US/Products-and-Services/SampleReports (accessed 20 July 2018).

Uhl-Bien, M. (2006), "Relational leadership theory: exploring the social processes of leadership and organizing", The Leadership Quarterly, Vol. 17 No. 6, pp. 654-676.

Von Schlippe, A. and Hermann, F. (2013), "The theory of social systems as a framework for understanding social businesses", Family Relations, Vol. 62 No. 3, pp. 384-398.

Ward, J.L. (2011), Keeping the Family Business Healthy-How to Plan for Continuing Growth, Profitability, and Family Leadership, Palgrave Macmillan, New York.

Weigel, D.J. and Weigel, R.R. (1993), "Intergenerational family communication: generational differences in rural families", Journal of Social and Personal Relationships, Vol. 10 No. 3, pp. 467-473.

Westhead, P., Wright, M. and Ucbasan, D. (2001), "The internationalization of new and small firms: a resource-based view", Journal of Business Venturing, Vol. 16 No. 4, pp. 333-358.

Witt, P. (2004), "Entrepreneurs' networks and the success of start-ups", Entrepreneurship and Regional Development, Vol. 16 No. 5, pp. 391-412.

Zehrer, A. and Haslwanter, J. (2010), "Management of change in tourism-the problem of family internal succession in family-run tourism SMEs", Electronic Journal of Family Business Management, Vol. 2 No. 4, pp. 147-162.

\section{Corresponding author}

Anita Zehrer can be contacted at: anita.zehrer@mci.edu

For instructions on how to order reprints of this article, please visit our website:

www.emeraldgrouppublishing.com/licensing/reprints.htm

Or contact us for further details: permissions@emeraldinsight.com 